$6-2-2005$

\title{
Synthesis and Characterization of Azole Isoflavone Inhibitors of Aromatase
}

John C. Hackett

Ohio State University

Young Woo Kim

Ohio State University

Bin Su

Cleveland State University, B.SU@csuohio.edu

Robert W. Brueggemeier

Ohio State University

Follow this and additional works at: https://engagedscholarship.csuohio.edu/scichem_facpub

Part of the Chemistry Commons

How does access to this work benefit you? Let us know!

\section{Recommended Citation}

Hackett, John C.; Kim, Young Woo; Su, Bin; and Brueggemeier, Robert W., "Synthesis and Characterization of Azole Isoflavone Inhibitors of Aromatase" (2005). Chemistry Faculty Publications. 413.

https://engagedscholarship.csuohio.edu/scichem_facpub/413

This Article is brought to you for free and open access by the Chemistry Department at EngagedScholarship@CSU. It has been accepted for inclusion in Chemistry Faculty Publications by an authorized administrator of EngagedScholarship@CSU. For more information, please contact library.es@csuohio.edu. 


\title{
Synthesis and characterization of azole isoflavone inhibitors of aromatase
}

\author{
John C Hackett, Young-Woo Kim, Bin Su and Robert W. Brueggemeier
}

\section{Introduction}

Estrogens are important in the growth of breast cancers in both pre- and post-menopausal women and, estrogen sensitivity in breast cancer increases with patient age. Two-thirds of breast cancer tumors in post-menopausal women are positive for estrogen and/or progesterone receptors, compared to pre-menopausal women where the presence of these receptors appears in less than half of tumors. The endogenous ligands for these receptors, estrogens and progestins, stimulate cell proliferation directly by increasing the rate of early response genes and indirectly through the stimulation of growth factors. ${ }^{1}$ Such dependence on sex steroids for tumor growth makes hormonal therapy an inviting strategy for treatment. $^{2}$

Two general strategies have developed for the treatment of hormone-dependent breast cancer. The first strategy is to block estrogen receptor action by disrupting its interaction with and activation by estradiol. Antiestrogens, such as tamoxifen, bind to the estrogen receptor and interfere with the transcription of estrogen-induced genes. The efficacy of tamoxifen has been established in the treatment of post-menopausal, hormone-responsive breast cancer. ${ }^{3}$ Tamoxifen increases long-term survival, reduces recurrences, and has few side effects. In addition to tamoxifen's antagonistic effects in breast tissue, it also behaves as a weak or partial agonist in other tissues. While exhibiting antagonistic activity in the breast, the partial agonist effects in other parts of the body have lead to the formation of secondary tumors of the liver and uterus. ${ }^{4}$ A second pharmacological approach is to block estradiol synthesis catalyzed by the cytochrome P450 enzyme aromatase (CYP19). Aromatase has been a particularly attractive target for inhibition in the treatment of hormone-dependent breast cancer since the aromatization of androgen substrates is the terminal and rate-limiting step in estrogen biosynthesis. ${ }^{5-8}$

In addition to the large number of aromatase inhibitors that have arisen from medicinal chemistry efforts in pharmaceutical and academic laboratories, ${ }^{5-9}$ a significant number of natural product aromatase inhibitors have been identified. ${ }^{10-12}$ The flavonoids are one of the largest classes of naturally occurring aromatase inhibitors. ${ }^{10}$ Generally, flavones and flavanones have higher aromatase inhibitory activity than isoflavones. Chrysin and Biochanin A (BCA) are two of the most potent examples of flavone and isoflavone identified to date, respectively (Fig. 1). The flavone, chrysin, is 20-fold more potent than BCA in terms of IC $_{50}$ values. ${ }^{11,12}$ This large difference in potency is the likely reason why there has been little effort to develop aromatase inhibitors on an isoflavone scaffold. 
<smiles>COc1ccc(-c2coc3cc(O)cc(O)c3c2=O)cc1</smiles><smiles>O=c1cc(-c2ccccc2)oc2cc(O)cc(O)c12</smiles>

(apparent $K \mathrm{i}=2.6 \pm 0.1 \mu \mathrm{M}$ )<smiles>O=c1c(-c2ccccc2)c(SCc2ccncc2)oc2cc(OCc3ccccc3)ccc12</smiles>

7-Benzyloxy-2-(4-pyridylmethylthio)isoflavone (apparent $K \mathrm{i}=0.22 \pm 0.02 \mu \mathrm{M}$ )

Figure 1. Chemical structures and aromatase inhibitory activities of biochanin A (isoflavone), ${ }^{14}$ chrysin (flavone), ${ }^{12}$ and the 7 benzyloxy 2 (4 pyridylmethylthio)isoflavone reported by our laboratory. ${ }^{14}$

Isoflavones have diverse pharmacological activities, ${ }^{13}$ and we envisioned introduction of the proper functional groups on the isoflavone core could result in the desired aromatase activity. Non-steroidal aromatase inhibitors developed to date are competitive inhibitors possessing a heteroatom that interferes with steroid hydroxylation by coordinating to the heme iron at the P450 active site. Although several heteroatoms, such as sulfur, oxygen, and nitrogen are capable of coordinating with the iron atom, the majority of these compounds possess a nitrogen-containing heterocycle such as imidazole, triazole, pyrimidine, or pyridine. ${ }^{9}$ In our previous work, we demonstrated that the introduction of a 2-(4-pyridylmethyl)thio functionality onto the isoflavone nucleus (Fig. 1) afforded a 160 -fold enhancement in potency compared to the natural product lead, BCA. ${ }^{14}$ This study demonstrated proof of the principle that introduction of appropriate nitrogen-containing heterocycle at the 2-position of the isoflavone nucleus is beneficial for aromatase inhibition. In addition, a hydrophobic functionality in the 7-position of the isoflavone and the reduced necessity of the $4^{\prime}$-substituent were important in achieving desirable affinity for the enzyme.

We have now focused on the synthesis of azole isoflavones, which were easily prepared by the phase transfer catalysis developed in our laboratory. ${ }^{15,16}$ In this series, we are interested in exploring the potential contribution of the imidazole, triazole, thioimidazole, and thiotriazole toward aromatase inhibition. Herein, we describe diversification of the 2-position of isoflavones and examine their contributions to the structure activity relationships of azole isoflavone aromatase inhibitors.

\section{Results and discussion}

The 2-(methylsulfonyl)isoflavones 1a d were prepared from the corresponding 2-(methylthio)isoflavones with $m$ CPBA using the method previously described by our laboratory. ${ }^{15,16}$ Azole isoflavones 2a d were prepared from 2-(methylsulfonyl)isoflavones 1a $\mathbf{d}$ and thioazole isoflavones 3a $\mathbf{d}$ were prepared from 1a in a single step in moderate to good yields by displacing the 2 methylsulfonyl group with various nucleophiles (Scheme $1)$.

Evaluation of the compounds for aromatase inhibitory activity was performed using the tritiated water release aromatase assay with human placental microsomes as the aromatase source, as previously reported by our laboratory. ${ }^{14} \mathrm{IC}_{50}$ values of the compounds were determined in dose response studies (Table 1). The $\mathrm{IC}_{50}$ values for $( \pm$ )-aminoglutethimide (AG) and BCA were also determined for comparison. Kinetic studies were undertaken on promising compounds to examine their mode of aromatase inhibition. The apparent $K_{\mathrm{i}}$ values for each compound, assay-specific apparent $K_{\mathrm{m}}$ values, and $K_{\mathrm{i}} / K_{\mathrm{m}}$ ratios are listed in Table 2. The Lineweaver Burk plot of compound $2 \mathrm{c}$ is shown in Figure 2.

In dose response studies (Table 1), 2-thioimidazole (3b,c) and 2-thiotriazole (3d) isoflavone analogs

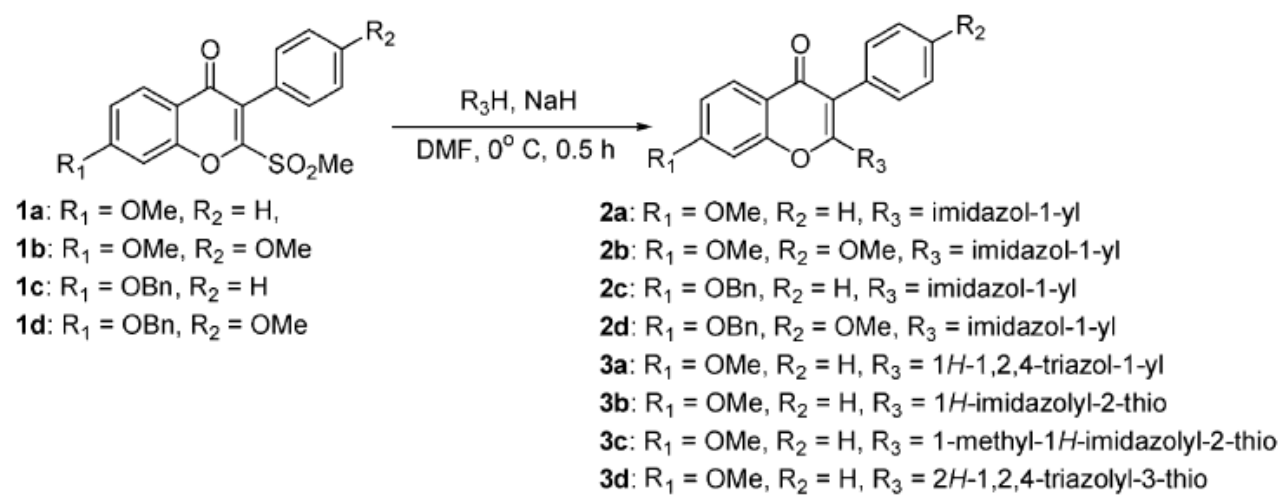


Table 1. $\mathrm{IC}_{50}$ values for aromatase inhibition by azole isoflavones and reference compounds

\begin{tabular}{lcl}
\hline & $\mathrm{IC}_{50}(\mu \mathrm{M})$ & $\log \mathrm{IC}_{50}(\mathrm{nM})( \pm \text { S.E. })^{\mathrm{a}}$ \\
\hline 2a & 0.77 & $2.89 \pm 0.04$ \\
2b & 2.0 & $3.29 \pm 0.04$ \\
2c & 0.52 & $2.71 \pm 0.03$ \\
2d & 4.7 & $3.67 \pm 0.09$ \\
3a & 18 & $4.26 \pm 0.09$ \\
3b & $>50$ & \\
3c & $>50$ & \\
3d & $>50$ & $3.45 \pm 0.05$ \\
AG & 2.8 & $4.53 \pm 0.06$ \\
BCA & 34 & \\
\hline
\end{tabular}

${ }^{\mathrm{a}} \mathrm{IC}_{50}$ values were calculated by nonlinear regression analysis in GraphPad Prism. Data for each dose response curve were obtained by evaluating aromatase inhibition at ten concentrations of the compound, each in triplicate.

Table 2. Enzyme kinetic parameters for imidazole isoflavones and reference compounds

\begin{tabular}{lcll}
\hline & Apparent $K_{\mathrm{i}}^{\mathrm{a}}$ & Apparent $K_{\mathrm{m}}{ }^{\mathrm{a}}$ & $K_{\mathrm{i}} / K_{\mathrm{m}}$ \\
\hline 2a & $0.68 \pm 0.04$ & $0.10 \pm 0.00$ & 6.8 \\
2b & $1.82 \pm 0.15$ & $0.10 \pm 0.01$ & 18 \\
2c & $0.25 \pm 0.02$ & $0.07 \pm 0.00$ & 3.6 \\
2d & $4.40 \pm 0.34$ & $0.12 \pm 0.01$ & 37 \\
AG & $1.41 \pm 0.10$ & $0.09 \pm 0.01$ & 16 \\
BCA & $12 \pm 5^{\mathrm{b}}$ & & \\
\hline
\end{tabular}

${ }^{a}$ Values were calculated by weighted regression analysis ${ }^{13}$ and expressed in $\mu \mathrm{M} \pm$ standard error.

${ }^{\mathrm{b}}$ Ref. 11.

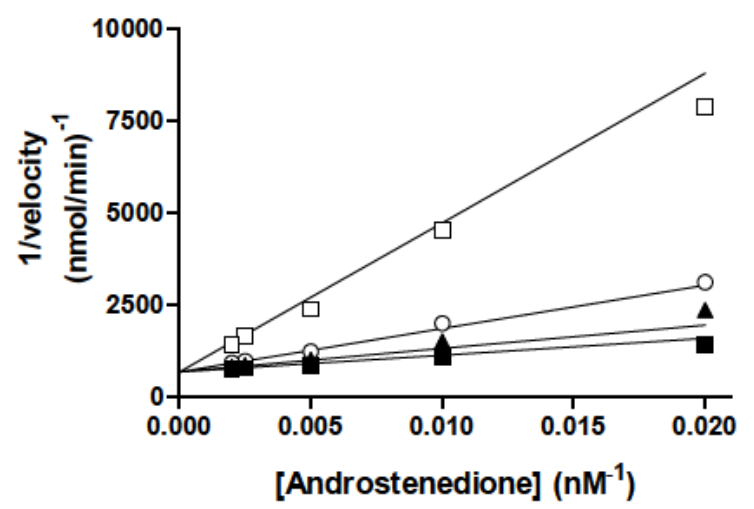

Figure 2. Lineweaver Burk plot of aromatase inhibition by compound 2c. Androstenedione at concentrations of $50500 \mathrm{nM}$ was incubated with microsomal enzyme preparations with inhibitor concentrations of $0 \mathrm{nM}(\boldsymbol{\square}), 100 \mathrm{nM}(\boldsymbol{\Delta}), 500 \mathrm{nM}(\bigcirc)$, and $2000 \mathrm{nM}(\square)$. Each point represents the mean of three determinations \pm standard error.

displayed poor or no inhibitory activity, with $\mathrm{IC}_{50}$ values greater than $50 \mu \mathrm{M}$. In contrast to the thioazole analogs, compounds with the heterocycle attached directly to the isoflavone scaffold showed promising inhibitory activity. The consequence of the nature of the azole heterocycle is exemplified by comparing the $\mathrm{IC}_{50}$ values of 7-methoxy analogs 2a and 3a. The imidazole analog 2a is 23 -fold more potent than the corresponding triazole. The increased potency of imidazole derivatives compared to triazole analogs was also observed in other non-steroidal aromatase inhibitors. ${ }^{9}$ Recanatini and coworkers previously postulated the coordinating ability of the nitrogen heterocycle is related to the distribution of the highest-occupied molecular orbital (HOMO) and the resulting electron density over the potentially ironcoordinating heterocycle. This postulate was used to partially rationalize the observed differences in potency between imidazomethyl-and triazomethyl-xanthones. ${ }^{17}$ To test this hypothesis, we fully optimized the geometries of $2 \mathrm{a}$ and $3 \mathrm{a}$ with the B3LYP ${ }^{18}$ hybrid density functional and 6-31G(d) basis set in the Gaussian $98^{19}$ suite of programs. The optimized geometries of these molecules share similar conformational preferences and may bind similarly to the aromatase active site (Fig. 3). As expected, the HOMO of the imidazole analog 2a is more densely localized on the nitrogen heterocycle than in 3a. Difference spectra of this pair of compounds were obtained with immunoaffinity-purified human placental aromatase (Hauptman Woodward Medical Research Institute, Buffalo, NY). Both compounds produce classical Type II spectra consistent with an increase in concentration of low-spin iron as a result of azole ligation. Compound 2a and 3a have absorption minima at 394 and $391 \mathrm{~nm}$, respectively, while both spectra have maxima at $430 \mathrm{~nm}$ (Fig. 4). The smaller change in absorbance induced by compound $\mathbf{3 a}$ is consistent with triazole being a weaker ligand for the
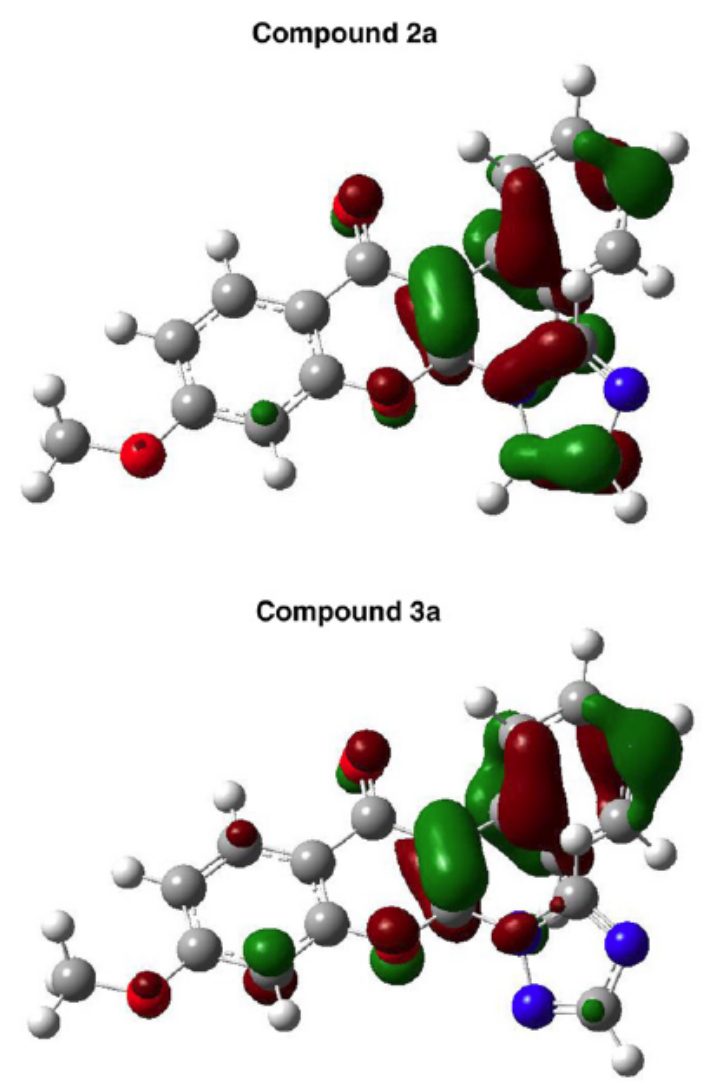

Figure 3. B3LYP/6 31G(d) optimized geometries of compound 2a (top) and compound 3a (bottom) displaying the surfaces of the highest occupied molecular orbital (HOMO). A contour value of $0.05 \mathrm{e} / \mathrm{B}^{3}$ was used. 


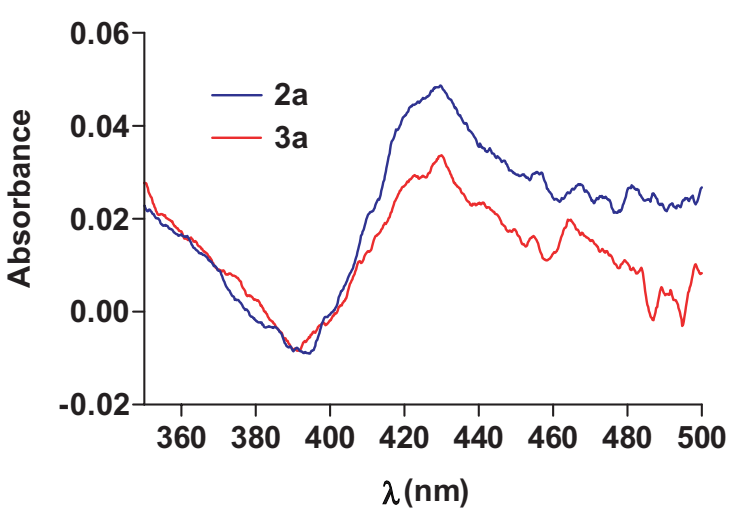

Figure 4. Type II difference spectra of immunoaffinity purified human placental aromatase induced by $50 \mu \mathrm{M}$ compound $2 \mathbf{a}$ (blue) and compound 3a (red).

heme iron. Taken together with the density functional theory (DFT) calculations, these observations explain the superior potency of the imidazole analog relies on the availability of the nitrogen lone pair electrons to coordinate with the aromatase P450 heme.

In general, imidazole isoflavone inhibitors presented in this work share similar structure activity relationships to those reported for 2-(4-pyridylmethyl)thioisoflavones. ${ }^{14}$ Regardless of the 7-substituent, a decrease in potency was observed when a methoxy group was introduced at the $4^{\prime}$-position. Additionally, the relative decrease in potency is dependent on the nature of the 7-substituent. 4',7-Dimethoxy analog, $\mathbf{2 b}$, is 2.6 -fold less potent than the 7-methoxy analog 2a. The loss of potency is more pronounced when considering the 7benzyloxy analogs. The presence of the $4^{\prime}$-methoxy in 2d results in a nine-fold loss of activity when compared to 2c. 4',7-Dimethoxy-(4-pyridylmethylthio)isoflavone and 7-benzyloxy-4'-methoxy-2-(4-pyridyl-methylthio)isoflavone are 1.2- and 2.5-times less active than their $4^{\prime}-\mathrm{H}$ analogs. This observation may indicate the nature of the 4 '-substituent may be a more important factor in the imidazole isoflavones in terms of aromatase inhibition.

In enzyme kinetic studies, imidazole isoflavones $\mathbf{2 a} \mathbf{~ d}$ demonstrated typical competitive-type inhibition in the Lineweaver Burk plots (Fig. 2 for $\mathbf{2}$; ; plots for $\mathbf{2 a}, \mathbf{b}, \mathbf{d}$ not shown) supporting their inhibition of aromatase by competing with the natural substrate for the active site. $K_{\mathrm{i}} / K_{\mathrm{m}}$ ratios of imidazole isoflavones were calculated as relative inhibitory potency and the same activity trend is observed as in the dose response studies. Compound 2c demonstrates 48 -fold enhancement in potency compared to the natural product lead, BCA. As reflected by its relative potency, imidazole analog $2 \mathrm{c}$ is 4.4 -fold more potent than the widely characterized inhibitor AG, which is in agreement within the expected experimental uncertainty of the result determined in the dose response studies (5.4-fold enhancement in potency compared to AG). The results of the present enzyme kinetic studies emphasize the importance of these structural modifications for optimization of aromatase inhibition by isoflavones.

\section{Conclusion}

Our recent work on 2-(4-pyridylmethylthio)isoflavones demonstrated for the first time that effective isoflavone-based aromatase inhibitors can be constructed by the introduction of appropriate nitrogen-containing heterocycle. This study further extends this concept that aromatase inhibitory activity can be achieved with the isoflavone nucleus by introduction of an appropriate heme-coordinating nitrogen heterocycle at the 2-position of the isoflavone. Comparable potency to the 2(4-pyridylmethylthio)isoflavones can be obtained by introducing an imidazole moiety at the 2-position. Enzyme kinetic analyses of imidazole isoflavones reveal these compounds interact competitively with the aromatase active site. As revealed by DFT calculations and the difference spectra of ligand binding, the superiority of this heterocycle to achieve aromatase inhibition may lie in the electronic structure of the nitrogen heterocycle itself. While investigations are currently underway to resolve further aspects of the enzyme ligand interactions, these compounds are additional leads in our repertoire of potent aromatase inhibitors.

\section{Experimental section}

\section{Chemistry}

Chemicals were commercially available and used as received without further purification, unless otherwise noted. Moisture sensitive reactions were carried out under a dry argon atmosphere in flame-dried glassware. Solvents were distilled before use under argon. Tetrahydrofuran was distilled from sodium metal in the presence of benzophenone; dichloromethane was distilled from calcium hydride. Thin layer chromatography was performed on pre-coated silica gel F254 plates (Whatman). Silica gel column chromatography was performed using silica gel 60A (Merck, 230-400 Mesh). Melting points were determined in open glass capillaries using a Thomas Hoover apparatus and are uncorrected. Infrared spectra were recorded on a Nicolet Protégé 460 spectrometer using $\mathrm{KBr}$ pellets. High-resolution electrospray ionization mass spectra were obtained on the Micromass QTOF Electrospray mass spectrometer at The Ohio State Chemical Instrumentation Center. All the NMR spectra were recorded on a Bruker DPX 250, or Bruker DRX 400 model spectrometer in either DMSO- $d_{6}$ or $\mathrm{CDCl}_{3}$. Chemical shifts $(\delta)$ for ${ }^{1} \mathrm{H}$ NMR spectra are reported in parts per million to residual solvent protons. Chemical shifts $(\delta)$ for ${ }^{13} \mathrm{C}$ NMR spectra are reported in parts per million relative to residual solvent carbons.

General method A for the preparation of 2-(alkylsulfonyl)isoflavones (1a-d)

A mixture of 7-alkoxy-3-aryl-2-(methylthio)-4H-1-benzopyran-4-one $(8.0 \mathrm{mmol})$ and 3-chloroperoxybenzoic acid ( $m$ CPBA) $(4.14 \mathrm{~g}, 24 \mathrm{mmol})$ in $\mathrm{CH}_{2} \mathrm{Cl}_{2}(80 \mathrm{~mL})$ were stirred under reflux for $2 \mathrm{~h}$. After the solvent was removed under reduced pressure, the residue was 
suspended in diethyl ether and hexane (1:1, $100 \mathrm{~mL})$, sonicated, and placed in a refrigerator overnight. The insoluble solid was collected by filtration, washed with diethyl ether and hexane (1:1) several times, and recrystallized from ethyl acetate to give desired product.

7-Methoxy-2-(methylsulfonyl)-3-phenyl-4H-1-benzopyran-4-one (1a). Compound 1a was synthesized from 7methoxy-2-(methylthio)-3-phenyl-4H-1-benzopyran-4one $(2.39 \mathrm{~g}, 8.0 \mathrm{mmol})$ using General Method A, and $2.59 \mathrm{~g}(98 \%)$ of the title compound was obtained as a pale yellow solid: mp $208210{ }^{\circ} \mathrm{C}$; HRMS calculated for $\mathrm{C}_{17} \mathrm{H}_{14} \mathrm{NaO}_{5} \mathrm{~S}(\mathrm{M}+\mathrm{Na})^{+} 353.0460$, found 353.0459 . IR $(\mathrm{KBr}) 1648,1622,1604,1569,1436,1326,1256$, $1203,1155,1134,1100,1052,1029,962,825,772,755$, $583 \mathrm{~cm}{ }^{1} ;{ }^{1} \mathrm{H}$ NMR $\left(400 \mathrm{MHz}\right.$, DMSO- $\left.d_{6}\right) \delta 7.94(\mathrm{~d}$, $J=8.9 \mathrm{~Hz}, \quad 1 \mathrm{H}), \quad 7.367 .38 \quad(\mathrm{~m}, \quad 3 \mathrm{H}), 7.34 \quad(\mathrm{~d}$, $J=2.3 \mathrm{~Hz}, 1 \mathrm{H}), 7.257 .27(\mathrm{~m}, 2 \mathrm{H}), 7.12(\mathrm{dd}, J=8.9$, $2.3 \mathrm{~Hz}, 1 \mathrm{H}), 3.91(\mathrm{~s}, 3 \mathrm{H}), 3.30(\mathrm{~s}, 3 \mathrm{H}) ;{ }^{13} \mathrm{C} \mathrm{NMR}$ $\left(100 \mathrm{MHz}, \mathrm{DMSO}-d_{6}\right) \delta 176.39,165.70,157.72,157.47$, $131.39,129.98,129.26,128.41,127.86,124.68,117.28$, $117.03,101.73,57.30,42.46$.

7-Methoxy-3-(4-methoxyphenyl)-2-(methylsulfonyl)-4H-1-benzopyran-4-one (1b). Compound $1 \mathrm{~b}$ was synthesized from 7-methoxy-3-(4-methoxyphenyl)-2-(methylthio)-4H-1-benzopyran-4-one $\quad(2.63 \mathrm{~g}, \quad 8.0 \mathrm{mmol})$ using General Method A, and $2.68 \mathrm{~g} \mathrm{(93 \% )} \mathrm{of} \mathrm{the} \mathrm{title}$ compound was obtained as a pale yellow solid: $\mathrm{mp}$ $227228.5^{\circ} \mathrm{C}$; HRMS calculated for $\mathrm{C}_{18} \mathrm{H}_{16} \mathrm{NaO}_{6} \mathrm{~S}$ $(\mathrm{M}+\mathrm{Na})^{+}$383.0565, found 383.0569. IR (KBr) 1646, $1618,1610,1570,1509,1438,1337,1311,1261,1246$, 1203, 1176, 1141, 1100, 1024, 973, 955, 849, 773, 588, $539,520,482 \mathrm{~cm}{ }^{1} ;{ }^{1} \mathrm{H}$ NMR (400 MHz, DMSO- $\left.d_{6}\right) \delta$ $7.94(\mathrm{~d}, J=8.9 \mathrm{~Hz}, 1 \mathrm{H}), 7.33(\mathrm{~d}, J=2.3 \mathrm{~Hz}, 1 \mathrm{H}), 7.19$ $(\mathrm{d}, J=8.6 \mathrm{~Hz}, 2 \mathrm{H}), 7.11(\mathrm{dd}, J=8.9,2.3 \mathrm{~Hz}, 1 \mathrm{H}), 6.94$ $(\mathrm{d}, J=8.7 \mathrm{~Hz}, 2 \mathrm{H}), 3.91(\mathrm{~s}, 3 \mathrm{H}), 3.77(\mathrm{~s}, 3 \mathrm{H}), 3.28(\mathrm{~s}$, $3 \mathrm{H}) ;{ }^{13} \mathrm{C}$ NMR $\left(100 \mathrm{MHz}, \mathrm{DMSO}-d_{6}\right) \delta 176.59,165.65$, $160.31,157.75,157.43,132.81,127.88,124.37,121.66$, $117.24,116.96,113.96,101.69,57.27,55.96,42.44$.

2-(Methylsulfonyl)-3-phenyl-7-(benzyloxy)-4H-1benzopyran-4-one (1c). Compound 1c was synthesized from 2-(methylthio)-3-phenyl-7-(benzyloxy)-4H-1-benzopyran-4-one (3.0 g, $8.0 \mathrm{mmol})$ using General Method A, and $3.12 \mathrm{~g}(96 \%)$ of the title compound was obtained as a white solid: mp $198199^{\circ} \mathrm{C}$; HRMS calculated for $\mathrm{C}_{23} \mathrm{H}_{18} \mathrm{NaO}_{5} \mathrm{~S}(\mathrm{M}+\mathrm{Na})^{+} 429.0773$, found 429.0761 . IR (KBr) 1651, 1620, 1568, 1499, 1440, 1332, 1256, 1161, $1140,1113,1027,1005,975,832,775,744,700$, $616 \mathrm{~cm}{ }^{1} ;{ }^{1} \mathrm{H}$ NMR $\left(400 \mathrm{MHz}\right.$, DMSO- $\left.d_{6}\right) \delta 7.95(\mathrm{~d}$, $J=8.9 \mathrm{~Hz}, 1 \mathrm{H}), 7.267 .48(\mathrm{~m}, 11 \mathrm{H}), 7.19(\mathrm{dd}, J=8.9$, $2.0 \mathrm{~Hz}, 1 \mathrm{H}), 5.28(\mathrm{~s}, 2 \mathrm{H}), 3.29(\mathrm{~s}, 3 \mathrm{H}) ;{ }^{13} \mathrm{C} \mathrm{NMR}$ $\left(100 \mathrm{MHz}, \mathrm{DMSO}-d_{6}\right) \delta 176.39,164.66,157.72,157.37$, $136.77,131.94,131.40,129.99,129.46,129.27,129.10$, $128.77,128.42,127.94,124.77,117.45,102.71,71.16$, 42.53 .

3-(4-Methoxyphenyl)-2-(methylsulfonyl)-7-(benzyloxy)-4H-1-benzopyran-4-one (1d). Compound 1d was synthesized from 2-(methylthio)-3-phenyl-7-(benzyloxy)4H-1-benzopyran-4-one (3.24 g, $8.0 \mathrm{mmol}$ ) using General Method A, and $3.39 \mathrm{~g}(97 \%)$ of the title compound was obtained as a white solid: mp $226227^{\circ} \mathrm{C}$; HRMS calculated for $\mathrm{C}_{24} \mathrm{H}_{20} \mathrm{NaO}_{6} \mathrm{~S}(\mathrm{M}+\mathrm{Na})^{+} 459.0878$, found 459.0868. IR (KBr) 1648, 1624, 1609, 1578, 1569, 1510, $1439,1332,1292,1248,1162,1138,1101,1030,972,840$, $827,774,698,613,536,525 \mathrm{~cm}{ }^{1} ;{ }^{1} \mathrm{H}$ NMR $(250 \mathrm{MHz}$, DMSO $\left.-d_{6}\right) \delta 7.95(\mathrm{~d}, J=8.9 \mathrm{~Hz}, 1 \mathrm{H}), 7.337 .49(\mathrm{~m}$, $6 \mathrm{H}), 7.177 .21(\mathrm{~m}, 3 \mathrm{H}), 6.94(\mathrm{~d}, J=8.7 \mathrm{~Hz}, 2 \mathrm{H}), 5.29$ $(\mathrm{s}, \quad 2 \mathrm{H}), \quad 3.77(\mathrm{~s}, \quad 3 \mathrm{H}), \quad 3.27(\mathrm{~s}, \quad 3 \mathrm{H}) ;{ }^{13} \mathrm{C}$ NMR $\left(62.9 \mathrm{MHz}, \quad\right.$ DMSO- $\left.d_{6}\right) \quad \delta \quad 176.57,164.60,160.32$, $157.75,157.32,136.79,132.83,129.46,129.10,128.77$, $127.95,124.45,121.67,117.41,117.38,113.97,101.67$, $71.14,55.96,42.51$.

\section{General Method B for nucleophilic substitution} reactions of 2-(alkylsulfonyl)isoflavones (2a-d and 3a-d)

A solution of 7-alkoxy-3-aryl-2-(methylsulfonyl)-4H-1benzopyran-4-one $(1.0 \mathrm{mmol})$ in DMF $(1 \mathrm{~mL})$ was added to a stirred solution of a nucleophile (as a sodium salt purchased or generated in situ by the treatment of sodium hydride) in DMF $(3 \mathrm{~mL})$ at $0{ }^{\circ} \mathrm{C}$. After stirring at $0{ }^{\circ} \mathrm{C}$ for $0.5 \mathrm{~h}$, most reactions were completed according to TLC. The reaction mixture was allowed to warm to room temperature over $1 \mathrm{~h}$, then cooled to $0{ }^{\circ} \mathrm{C}$, and quenched with saturated aqueous $\mathrm{NH}_{4} \mathrm{Cl}$ solution. After the volatile solvents were removed in vacuo, the residual solid was suspended in a mixture of water and EtOAc, ultrasonicated for $5 \mathrm{~min}$, and cooled to $0{ }^{\circ} \mathrm{C}$. Insoluble solid was collected by filtration and the filter cake was washed with EtOAc/hexane mixture to give desire product. The filtrate was extracted with EtOAc twice $(2 \times 10 \mathrm{~mL})$, and the combined organic layer was washed with brine, dried over $\mathrm{MgSO}_{4}$, filtered, and concentrated under reduced pressure. The remnant was purified by silica gel column chromatography (eluting with $\mathrm{MeOH} / \mathrm{CHCl}_{3}$ ) to collect additional product. The combined solid was further purified by recrystallization.

2-(1H-Imidazol-1-yl)-7-methoxy-3-phenyl-4H-1-benzopyran-4-one (2a). Compound 2a was synthesized from 7methoxy-2-(methylsulfonyl)-3-phenyl-4H-1-benzopyran4-one $(0.330 \mathrm{~g}, 1.0 \mathrm{mmol})$ and sodium salt of imidazole $(0.180 \mathrm{~g}, 2.0 \mathrm{mmol}$, purchased) using General Method $\mathrm{B}$, and $0.231 \mathrm{~g}(73 \%)$ of the title compound was obtained as a white solid (recrystallized from EtOAc): mp 217 $219^{\circ} \mathrm{C}$; HRMS calculated for $\mathrm{C}_{19} \mathrm{H}_{15} \mathrm{~N}_{2} \mathrm{O}_{3}(\mathrm{M}+\mathrm{H})^{+}$ 319.1082, found 319.1060. IR ( $\mathrm{KBr}) 1640,1619,1575$, $1492,1441,1404,1342,1266,1255,1201,1104,1053$, $1016,953,908,834,784,754,738,703,648 \mathrm{~cm}^{1} ;{ }^{1} \mathrm{H}$ NMR $\left(400 \mathrm{MHz}\right.$, DMSO- $\left.d_{6}\right) \delta 7.98(\mathrm{~d}, J=8.9 \mathrm{~Hz}$, $1 \mathrm{H}), \quad 7.71 \quad(\mathrm{~s}, \quad 1 \mathrm{H}), \quad 7.31 \quad 7.33 \quad(\mathrm{~m}, \quad 3 \mathrm{H}), 7.28 \quad(\mathrm{~d}$, $J=2.4 \mathrm{~Hz}, 1 \mathrm{H}), 7.177 .20(\mathrm{~m}, 3 \mathrm{H}), 7.12(\mathrm{dd}, J=8.9$, $2.4 \mathrm{~Hz}, 1 \mathrm{H}), 6.93(\mathrm{~s}, 1 \mathrm{H}), 3.89(\mathrm{~s}, 3 \mathrm{H}) ;{ }^{13} \mathrm{C} \mathrm{NMR}$ $\left(100 \mathrm{MHz}, \mathrm{DMSO}-d_{6}\right) \delta 176.84,165.15,156.61,151.04$, $138.23,131.39,131.04,129.92,129.21,129.00,127.81$, $120.31,116.99,166.20,116.18,101.65,57.14$. Elemental analysis: Calcd for $\mathrm{C}_{19} \mathrm{H}_{14} \mathrm{~N}_{2} \mathrm{O}_{3}(\%)$ : $\mathrm{C}, 71.69 ; \mathrm{H}, 4.43$; $\mathrm{N}, 8.80$. Found: $\mathrm{C}, 71.56 ; \mathrm{H}, 4.49 ; \mathrm{N}, 8.78$.

2-(1 H-Imidazol-1-yl)-7-methoxy-3-(4-methoxyphenyl)-4H-1-benzopyran-4-one (2b). Compound $2 \mathrm{~b}$ was synthesized from 7-methoxy-3-(4-methoxyphenyl)-2-(methylsulfonyl)-4H-1-benzopyran-4-one $(0.36 \mathrm{~g}, 1.0 \mathrm{mmol})$ 
and sodium salt of imidazole $(0.180 \mathrm{~g}, 2.0 \mathrm{mmol}$, purchased) using General Method B, and $0.324 \mathrm{~g}(93 \%)$ of the title compound was obtained as a white solid (recrystallized from EtOH): mp $232233^{\circ} \mathrm{C}$; HRMS calculated for $\mathrm{C}_{20} \mathrm{H}_{16} \mathrm{~N}_{2} \mathrm{NaO}_{4}(\mathrm{M}+\mathrm{Na})^{+} 371.1008$, found 371.1015. IR (KBr) 1639, 1611, 1578, 1515, 1441, 1405, 1342, $1291,1253,1201,1174,1054,1024,831,816$, $747 \mathrm{~cm}{ }^{1} ;{ }^{1} \mathrm{H}$ NMR $\left(400 \mathrm{MHz}, \mathrm{CDCl}_{3}\right) \delta 8.15(\mathrm{~d}$, $J=8.9 \mathrm{~Hz}, 1 \mathrm{H}), 7.62(\mathrm{~s}, 1 \mathrm{H}), 7.12(\mathrm{~d}, J=8.7 \mathrm{~Hz}$, $2 \mathrm{H}), 7.007 .03(\mathrm{~m}, 2 \mathrm{H}), 6.96(\mathrm{~s}, 1 \mathrm{H}), 6.896 .91(\mathrm{~m}$, $3 \mathrm{H}), 3.92(\mathrm{~s}, 3 \mathrm{H}), 3.80(\mathrm{~s}, 3 \mathrm{H}) ;{ }^{13} \mathrm{C}$ NMR $(100 \mathrm{MHz}$, $\left.\mathrm{CDCl}_{3}\right) \delta 177.20,164.98,160.18,156.18,150.21$, $137.22,131.71,130.38,128.41,122.28,118.77,117.12$, $115.46,115.01,114.43,100.46,56.41,55.67$. Elemental analysis: Calcd for $\mathrm{C}_{20} \mathrm{H}_{16} \mathrm{~N}_{2} \mathrm{O}_{4}(\%)$ : C, 68.96; H, 4.63; N, 8.04. Found: C, 68.73; H, 4.72; N, 7.94.

2-(1 H-Imidazol-1-yl)-3-phenyl-7-(benzyloxy)-4H1-benzopyran-4-one (2c). Compound $2 \mathrm{c}$ was synthesized from 2-(methylsulfonyl)-3-phenyl-7-(benzyloxy)-4H-1benzopyran-4-one $(0.41 \mathrm{~g}, 1.0 \mathrm{mmol})$ and sodium salt of imidazole $(0.180 \mathrm{~g}, 2.0 \mathrm{mmol}$, purchased) using General Method B, and $0.323 \mathrm{~g} \mathrm{(82 \% )}$ of the title compound was obtained as a white solid (recrystallized from EtOAc): $\mathrm{mp} 152153^{\circ} \mathrm{C}$; HRMS calculated for $\mathrm{C}_{25} \mathrm{H}_{19} \mathrm{~N}_{2} \mathrm{O}_{3}(\mathrm{M}+\mathrm{H})^{+}$395.1395, found 395.1396. IR (KBr) 1633, 1610, 1572, 1494, 1441, 1402, 1389, 1336, 1251, 1193, 1150, 1103, 1094, 1051, 1017, 991, 908, 839, 790, 740, $699 \mathrm{~cm}{ }^{1} ;{ }^{1} \mathrm{H}$ NMR $\left(400 \mathrm{MHz}, \mathrm{CDCl}_{3}\right)$ $\delta 8.17(\mathrm{~d}, J=8.9 \mathrm{~Hz}, 1 \mathrm{H}), 7.58(\mathrm{~s}, 1 \mathrm{H}), 7.357 .45(\mathrm{~m}$, $8 \mathrm{H}), 7.197 .21(\mathrm{~m}, 2 \mathrm{H}), 7.10(\mathrm{dd}, J=8.9,2.3 \mathrm{~Hz}, 1 \mathrm{H})$, $6.99(\mathrm{~s}, 1 \mathrm{H}), 6.97(\mathrm{~d}, J=2.3 \mathrm{~Hz}, 1 \mathrm{H}), 6.92(\mathrm{~s}, 1 \mathrm{H})$, $5.19(\mathrm{~s}, 2 \mathrm{H}) ;{ }^{13} \mathrm{C}$ NMR $\left(100 \mathrm{MHz}, \mathrm{CDCl}_{3}\right) \delta 176.90$, $164.06,156.12$, 150.35, 137.19, 135.85, 130.53, 130.41, $129.47,129.26,129.13,128.96,128.49,127.91,118.77$, $117.32,116.08,114.82,101.58,71.14$. Elemental analysis: Calcd for $\mathrm{C}_{25} \mathrm{H}_{18} \mathrm{~N}_{2} \mathrm{O}_{3}(\%)$ : C, 76.13; H, 4.60; N, 7.10. Found: C, 76.24; H, 4.71; N, 7.10.

2-(1 H-Imidazol-1-yl)-3-(4-methoxyphenyl)-7-(benzyloxy)-4H-1-benzopyran-4-one (2d). Compound 2d was synthesized from 3-(4-methoxyphenyl)-2-(methylsulfonyl)-7-(benzyloxy)-4H-1-benzopyran-4-one $(0.71 \mathrm{~g}$, $1.63 \mathrm{mmol})$ and sodium salt of imidazole $(0.30 \mathrm{~g}$, $3.25 \mathrm{mmol}$, purchased) using General Method B, and $0.604 \mathrm{~g}(87 \%)$ of the title compound was obtained as a white solid (recrystallized from EtOAc): mp 160 $161{ }^{\circ} \mathrm{C}$; HRMS calculated for $\mathrm{C}_{26} \mathrm{H}_{21} \mathrm{~N}_{2} \mathrm{O}_{4}(\mathrm{M}+\mathrm{H})^{+}$ 425.1501, found 425.1511. IR ( $\mathrm{KBr}) 1637,1613,1577$, $1512,1439,1403,1339,1293,1245,1194,1175,1098$, $1055,1018,908,823,748,700,654 \mathrm{~cm}^{1} ;{ }^{1} \mathrm{H}$ NMR $\left(400 \mathrm{MHz}, \mathrm{CDCl}_{3}\right) \delta 8.16(\mathrm{~d}, J=8.9 \mathrm{~Hz}, 1 \mathrm{H}), 7.61(\mathrm{~s}$, 1H), $7.367 .45(\mathrm{~m}, 5 \mathrm{H}), 7.12(\mathrm{~d}, J=8.7 \mathrm{~Hz}, 2 \mathrm{H}), 7.09$ $(\mathrm{dd}, \quad J=8.9,2.3 \mathrm{~Hz}, 1 \mathrm{H}), 7.00(\mathrm{~s}, 1 \mathrm{H}), 6.96(\mathrm{~d}$, $J=2.3 \mathrm{~Hz}, 1 \mathrm{H}), 6.95(\mathrm{~s}, 1 \mathrm{H}), 6.90(\mathrm{~d}, J=8.7 \mathrm{~Hz}, 2 \mathrm{H})$, $5.18(\mathrm{~s}, 2 \mathrm{H}), 3.80(\mathrm{~s}, 3 \mathrm{H}) ;{ }^{13} \mathrm{C}$ NMR $\left(100 \mathrm{MHz}, \mathrm{CDCl}_{3}\right)$ $\delta 177.17,163.99,160.19,156.09,150.23,137.22,135.87$, $131.70,130.38,129.25,128.94,128.49,127.90,122.25$, $118.77,117.31,116.01,115.02,114.47,101.54,71.12$, 55.67. Elemental analysis: Calcd for $\mathrm{C}_{26} \mathrm{H}_{20} \mathrm{~N}_{2} \mathrm{O}_{4}(\%)$ : C, 73.57; H, 4.75; N, 6.60. Found: C, 73.54; H, 4.82; $\mathrm{N}, 6.55$.
7-Methoxy-3-phenyl-2-(1H-1,2,4-triazol-1-yl)-4H1-benzopyran-4-one (3a). Compound 3a was synthesized from 7-methoxy-2-(methylsulfonyl)-3-phenyl-4H-1-benzopyran-4-one $(0.165 \mathrm{~g}, 0.5 \mathrm{mmol})$ and sodium salt of 1,2,4-triazole (0.091 g, $1.0 \mathrm{mmol}$, purchased) using General Method B, and $0.144 \mathrm{~g}(90 \%)$ of the title compound was obtained as a white solid (recrystallized from EtOAc): $\mathrm{mp} 188.5189 .5^{\circ} \mathrm{C}$; HRMS calculated for $\mathrm{C}_{18} \mathrm{H}_{13} \mathrm{~N}_{3} \mathrm{NaO}_{3}(\mathrm{M}+\mathrm{Na})^{+}$342.0855, found 342.0843 . IR $(\mathrm{KBr}) 1643,1619,1575,1502,1429,1337,1262$, $1217,1203,1124,1104,1060,993,920,837,831,785$, $755,705,662 \mathrm{~cm}{ }^{1} ;{ }^{1} \mathrm{H}$ NMR (400 MHz, DMSO- $\left.d_{6}\right) \delta$ $8.63(\mathrm{~s}, 1 \mathrm{H}), 8.21(\mathrm{~s}, 1 \mathrm{H}), 8.01(\mathrm{~d}, J=8.9 \mathrm{~Hz}, 1 \mathrm{H})$, $7.287 .29(\mathrm{~m}, 4 \mathrm{H}), 7.117 .16(\mathrm{~m}, 3 \mathrm{H}), 3.89(\mathrm{~s}, 3 \mathrm{H}) ;{ }^{13} \mathrm{C}$ NMR $\left(100 \mathrm{MHz}, \mathrm{DMSO}-d_{6}\right) \delta 176.56,165.48,156.70$, $153.62,150.08,147.29,130.79,130.67,129.01,128.92$, 127.98, 119.39, 117.14, 116.57, 101.69, 57.25. Elemental analysis: Calcd for $\mathrm{C}_{18} \mathrm{H}_{13} \mathrm{~N}_{3} \mathrm{O}_{3}(\%)$ : $\mathrm{C}, 67.71 ; \mathrm{H}, 4.10$; N, 13.16. Found: C, 67.60; H, 4.14; N, 13.06.

2-(1 $H$-Imidazolyl-2-thio)-7-methoxy-3-phenyl-4H1-benzopyran-4-one (3b). Compound $\mathbf{3 b}$ was synthesized from 7-methoxy-2-(methylsulfonyl)-3-phenyl-4H-1-benzopyran-4-one $(0.165 \mathrm{~g}, 0.5 \mathrm{mmol}), 2$-mercaptoimidazole $(0.153 \mathrm{~g}, 1.5 \mathrm{mmol})$, and sodium hydride $(0.036 \mathrm{~g}$, $1.5 \mathrm{mmol})$ using General Method B, and $0.156 \mathrm{~g}(89 \%)$ of the title compound was obtained as a white solid (recrystallized from EtOH): mp $248250^{\circ} \mathrm{C}$ (decomposed); HRMS calculated for $\mathrm{C}_{19} \mathrm{H}_{14} \mathrm{~N}_{2} \mathrm{NaO}_{3} \mathrm{~S}$ $(\mathrm{M}+\mathrm{Na})^{+}$373.0623, found 373.0640. IR $(\mathrm{KBr}) 3434$, $1622,1589,1537,1437,1376,1349,1331,1260,1205$, 1104, 1028, 939, 831, 784, 760, $711 \mathrm{~cm}{ }^{1} ;{ }^{1} \mathrm{H}$ NMR $\left(400 \mathrm{MHz}, \mathrm{DMSO}-d_{6}\right) \delta 12.95$ (br s, $\left.1 \mathrm{H}\right), 7.91$ (d, $J=8.9 \mathrm{~Hz}, 1 \mathrm{H}), 7.387 .47(\mathrm{~m}, 4 \mathrm{H}), 7.337 .35(\mathrm{~m}, 2 \mathrm{H})$, $7.11(\mathrm{~s}, 1 \mathrm{H}), 7.04(\mathrm{dd}, J=8.9,2.3 \mathrm{~Hz}, 1 \mathrm{H}), 6.55(\mathrm{~d}$, $J=2.3 \mathrm{~Hz}, 1 \mathrm{H}), 3.81(\mathrm{~s}, 3 \mathrm{H}) ;{ }^{13} \mathrm{C}$ NMR $(100 \mathrm{MHz}$, DMSO- $\left.d_{6}\right) \delta 173.85,164.59,160.91,158.42,132.57$, $131.69,131.48,130.14,129.27,129.19,127.97,123.41$, $122.38,117.12,115.75,100.79,56.99$. Elemental analysis: Calcd for $\mathrm{C}_{19} \mathrm{H}_{14} \mathrm{~N}_{2} \mathrm{O}_{3} \mathrm{~S}(\%)$ : $\mathrm{C}, 71.69 ; \mathrm{H}, 4.43 ; \mathrm{N}$, 8.80. Found: C, 71.56; H, 4.49; N, 8.78.

7-Methoxy-2-(1-methyl-1H-imidazolyl-2-thio)-3-phenyl-4H-1-benzopyran-4-one (3c). Compound $3 \mathrm{c}$ was synthesized from 7-methoxy-2-(methylsulfonyl)-3-phenyl$4 H$-1-benzopyran-4-one $(0.165 \mathrm{~g}, 0.5 \mathrm{mmol}), 2$-mercapto-1-methylimidazole $(0.171 \mathrm{~g}, 1.5 \mathrm{mmol})$, and sodium hydride $(0.036 \mathrm{~g}, 1.5 \mathrm{mmol})$ using General Method B, and $0.175 \mathrm{~g}(96 \%)$ of the title compound was obtained as a white solid (recrystallized from EtOAc): $\quad 172173{ }^{\circ} \mathrm{C}$; HRMS calculated for $\mathrm{C}_{20} \mathrm{H}_{17} \mathrm{~N}_{2} \mathrm{O}_{3} \mathrm{~S}(\mathrm{M}+\mathrm{H})^{+}$365.0960, found 365.0955. IR (KBr) 1640, 1618, 1590, 1499, 1437, 1368, 1344, 1253, $1198,1099,1016,939,783,756,698 \mathrm{~cm}{ }^{1} ;{ }^{1} \mathrm{H}$ NMR $\left(400 \mathrm{MHz}, \mathrm{DMSO}-d_{6}\right) \delta 7.90(\mathrm{~d}, J=9.0 \mathrm{~Hz}, 1 \mathrm{H}), 7.51$ $(\mathrm{d}, J=1.0 \mathrm{~Hz}, 1 \mathrm{H}), 7.407 .48(\mathrm{~m}, 3 \mathrm{H}), 7.347 .36(\mathrm{~m}$, $2 \mathrm{H}), 7.11(\mathrm{~d}, J=1.2 \mathrm{~Hz}, 1 \mathrm{H}), 7.03(\mathrm{dd}, J=9.0,2.3 \mathrm{~Hz}$, $1 \mathrm{H}), 6.57(\mathrm{~d}, J=2.3 \mathrm{~Hz}, 1 \mathrm{H}), 3.82(\mathrm{~s}, 3 \mathrm{H}), 3.68(\mathrm{~s}$, $3 \mathrm{H}) ;{ }^{13} \mathrm{C}$ NMR $\left(100 \mathrm{MHz}\right.$, DMSO- $\left.d_{6}\right) \quad \delta \quad 173.88$, $164.60,160.85,158.42,132.59,131.89,131.46,131.06$, $129.30,129.22,127.98,126.94,123.53,117.15,115.70$, 100.96, 57.02, 34.68. Elemental analysis: Calcd for 
$\mathrm{C}_{20} \mathrm{H}_{16} \mathrm{~N}_{2} \mathrm{O}_{3} \mathrm{~S}(\%): \mathrm{C}, 65.92 ; \mathrm{H}, 4.43 ; \mathrm{N}, 7.69$. Found: $\mathrm{C}$, $65.68 ; \mathrm{H}, 4.46 ; \mathrm{N}, 7.62$.

7-Methoxy-3-phenyl-2-(1 H-1,2,4-triazolyl-3-thio)4H-1-benzopyran-4-one (3d). Compound 3d was synthesized from 7-methoxy-2-(methylsulfonyl)-3-phenyl-4H1-benzopyran-4-one $(0.165 \mathrm{~g}, 0.5 \mathrm{mmol}), 1 \mathrm{H}$-1,2,4-triazole-3-thiol $(0.152 \mathrm{~g}, 1.5 \mathrm{mmol})$, and sodium hydride $(0.036 \mathrm{~g}, 1.5 \mathrm{mmol})$ using General Method B, and $0.075 \mathrm{~g}(43 \%)$ of the title compound was obtained as a pale yellow solid (recrystallized from $\mathrm{EtOH}$ ): mp 246 $247^{\circ} \mathrm{C}$; HRMS calculated for $\mathrm{C}_{18} \mathrm{H}_{13} \mathrm{~N}_{3} \mathrm{NaO}_{3} \mathrm{~S}$ $(\mathrm{M}+\mathrm{Na})^{+}$374.0575, found 374.0586. IR (KBr) 1612, $1582,1502,1440,1379,1349,1262,1201,1185,1104$ $1014,969,939,830,783,758,700 \mathrm{~cm}^{1} ;{ }^{1} \mathrm{H}$ NMR $\left(400 \mathrm{MHz}, \quad\right.$ DMSO- $\left.d_{6}\right) \quad \delta \quad 8.69 \quad(\mathrm{~s}, \quad 1 \mathrm{H}), \quad 7.91 \quad(\mathrm{~d}$, $J=8.9 \mathrm{~Hz}, 1 \mathrm{H}), 7.367 .45(\mathrm{~m}, 3 \mathrm{H}), 7.327 .34(\mathrm{~m}, 2 \mathrm{H})$, $7.04(\mathrm{dd}, J=8.9,2.3 \mathrm{~Hz}, 1 \mathrm{H}), 6.73(\mathrm{~d}, J=2.3 \mathrm{~Hz}, 1 \mathrm{H})$, $3.81(\mathrm{~s}, 3 \mathrm{H}) ;{ }^{13} \mathrm{C}$ NMR $\left(100 \mathrm{MHz}, \mathrm{DMSO}-d_{6}\right) \delta 174.51$, $164.83,159.47,158.67,146.80,132.74,131.27,129.33$, $129.17,127.96,126.01,117.02,116.01,100.81,56.99$. Elemental analysis: Calcd for $\mathrm{C}_{18} \mathrm{H}_{13} \mathrm{~N}_{3} \mathrm{O}_{3} \mathrm{~S}(\%)$ : C, 61.53; H, 3.73; N, 11.96. Found: C, 61.27; H, 3.76; N, 11.86.

\section{Enzymology}

Preparation of human placental microsomes. Human term placentas were processed immediately after delivery from The Ohio State University Hospitals at $4{ }^{\circ} \mathrm{C}$. The placenta was washed with normal saline and connective and vascular tissue was removed. Microsomes were prepared from the remaining tissue using the method described by Kellis and Vickery. ${ }^{20}$ Microsomal suspensions were stored at $-80^{\circ} \mathrm{C}$ until required.

Inhibition study. Inhibition of human placental aromatase was determined by monitoring the amount of ${ }^{3} \mathrm{H}_{2} \mathrm{O}$ released as the enzyme converts $\left[1 \beta-{ }^{3} \mathrm{H}\right]$ androst-4-ene-3,17-dione to estrone. Ten inhibitor concentrations ranging from $100 \mathrm{nM}$ to $50 \mu \mathrm{M}$ were evaluated. Aromatase activity assays were carried in $0.1 \mathrm{M}$ potassium phosphate buffer $(\mathrm{pH} 7.0)$ with $5 \%$ propylene glycol. All samples contained a NADPH regenerating system consisting of $2.85 \mathrm{mM}$ glucose-6phosphate, $1.8 \mathrm{mM} \mathrm{NADP}{ }^{+}$and 1.5 units of glucose6-phosphate dehydrogenase (Sigma, St. Louis, MO). Samples contained $100 \mathrm{nM}$ androst-4-ene-3,17-dione $(400,000450,000 \mathrm{dpm})$. Reactions were initiated with the addition of $50 \mu \mathrm{g}$ microsomal protein. The total incubation volume was $2.0 \mathrm{~mL}$. Incubations were allowed to proceed for $15 \mathrm{~min}$ in a shaking water bath at $37^{\circ} \mathrm{C}$. Reactions were quenched by the addition of $2.0 \mathrm{~mL}$ of chloroform. Samples were then vortexed and centrifuged for $5 \mathrm{~min}$ and the aqueous layer was removed. The aqueous layer was subsequently extracted twice in the same manner with $2.0 \mathrm{~mL}$ chloroform. A $0.5 \mathrm{~mL}$ aliquot of the final aqueous layer was combined with $5 \mathrm{~mL}$ 3a70B scintillation cocktail (Research Products International Corp., Mt. Prospect, IL) and the amount of radioactivity determined. Each sample was run in triplicate and background values were determined with microsomal protein inactivated by boiling. Samples containing $50 \mu \mathrm{M}( \pm)$ aminoglutethimide (Sigma, St.
Louis, MO) were used a positive control. $\mathrm{IC}_{50}$ dose response data were analyzed with the Graphpad Prism (Version 3.0) program.

Kinetic study. Enzyme kinetic studies of compounds 2a d were conducted to investigate the nature of aromatase inhibition. Michaelis-Menten enzyme kinetic parameters were determined by varying the concentration of androst-4-ene-3,17-dione from 50 to $500 \mathrm{nM}$ in the presence of a fixed concentrations of 0 , $100,500,2000 \mathrm{nM}(\mathbf{2 a}, \mathbf{c})$ and 0, 2000, 5000, 10,000 nM $(\mathbf{2 b}, \mathbf{d})$. Assay conditions were the same as those described in the $\mathrm{IC}_{50}$ studies except reactions were initiated by the addition of $15 \mu \mathrm{g}$ microsomal protein. Analysis of the enzyme kinetic data was performed with the weighted linear regression analysis previously described by Cleland. ${ }^{21}$

Determination of $\mathbf{P 4 5 0}$ difference spectra. Immunoaffinity-purified human placental cytochrome P450 aromatase (Hauptman-Woodward Medical Research Institute, Buffalo, NY) was diluted to $7.0 \mu \mathrm{g} / \mathrm{mL}$ with $0.1 \mathrm{M}$ Tris Buffer ( $\mathrm{pH} 7.4$ ) in a $50 \mu \mathrm{L}$ quartz UV cell, and the absorbance was scanned from 350 to $500 \mathrm{~nm}$. $0.1 \mathrm{M}$ Tris Buffer (pH 7.4) was used as a reference. Compounds $2 \mathbf{a}$ and $\mathbf{3 a}$ were introduced into the sample cell in $1 \mu \mathrm{L}$ of ethanol for a final concentration of $50 \mu \mathrm{M}$, and the spectrum was rescanned at the aforementioned wavelength range. Multiple scans were taken to ensure spectrum stability for aromatase and aromatase/inhibitor mixtures. Absorbance values of aromatase were subtracted from the aromatase/inhibitor values to generate the difference spectrum.

\section{Acknowledgements}

This research was supported by a USAMRMC Breast Cancer Program grants Pre-doctoral Fellowship DMAD17-02-1-0529 (J.C.H.), DMAD17-99-1-9342 (Y.W.K.), and Idea Grant DMAD-17-00-1-0388 (R.W.B.). The authors are indebted to the Ohio Supercomputer Center for computational resources.

\section{References and notes}

1. Dickson, R. B.; Lippman, M. E. Endocrine Rev. 1995, 16, 559.

2. McGuire, W. L. In Hormones and Cancer; Iacobelli, S., King, R. J. B., Lidner, H. R., Lippman, M. E., Eds.; Raven: New York, 1980; Vol. 15, pp 337344.

3. Early Breast Cancer Trialist's Group Lancet 1992, 339, 1.

4. Jordan, V. C. Ann. Rev. Pharmacol. Toxicol. 1995, 35, 195.

5. Brodie, A.; Lu, Q.; Long, B. J. Steroid. Biochem. Mol. Biol. 1999, 69, 205.

6. Santen, R. J.; Harvey, H. A. Endocr. Relat. Cancer 1999, 6, 75 .

7. Brueggemeier, R. W. Am. J. Ther. 2001, 8, 333.

8. Brueggemeier, R. W. Expert Rev. Anticancer Ther. 2002, 2 , 181.

9. Recanatini, M.; Cavalli, A.; Valenti, P. Med. Res. Rev. 2002, 22, 282. 
10. Hodek, P.; Trefil, P.; Stiborová, M. Chem. Biol. Interact. 2002, 139, 1.

11. Kao, Y. C.; Zhou, C.; Sherman, M.; Laughton, C. A.; Chen, S. Environ. Health Perspect. 1998, 106, 85.

12. Kellis, J. T., Jr.; Vickery, L. E. Science 1984, 225, 1032.

13. Ren, W.; Qiao, Z.; Wang, H.; Zhu, L.; Zhang, L. Med. Res. Rev. 2003, 23, 519.

14. Kim, Y. W.; Hackett, J. C; Brueggemeier, R. W. J. Med. Chem. 2004, 47, 4032.

15. Kim, Y. W.; Brueggemeier, R. W. Tetrahedron Lett. 2002 , 43,6113
16. Kim, Y. W.; Mobley, J. A.; Brueggemeier, R. W. Bioorg. Med. Chem. Lett. 2003, 13, 1475.

17. Recanatini, M.; Bisi, A.; Cavalli, A.; Belluti, F.; Gobbi, S.; Rampa, A.; Valenti, P.; Palzer, M.; Palusczak, A.; Hartmann, R. W. J. Med. Chem. 2001, 44, 672.

18. Stevens, P. J.; Devlin, F. J.; Chablowski, C. F.; Frisch, M. J. J. Phys. Chem. 1994, 98, 11623.

19. Gaussian 98, Revision A.11.3. Frisch, M. J. et al. Gauss ian, Inc. Pittsburgh, PA, 2002.

20. Kellis, J. T., Jr.; Vickery, L. E. J. Biol. Chem. 1987, 262, 4413.

21. Cleland, W. W. Method. Enzymol. 1979, 63, 103. 